\title{
GROWTH OF SEEDLINGS OF PIGEON PEA (Cajanus cajan (L.) MILLSP), WAND RIVERHEMP (Sesbania virgata (CAV.) PERS.), AND LEAD TREE (Leucaena leucocephala (LAM.) DE WIT) IN AN ARSENIC-CONTAMINATED SOIL ${ }^{(1)}$
}

\author{
Luiz Eduardo Dias ${ }^{(2)}$, Roseli Freire Melo(3), Jaime Wilson Vargas de \\ Mello $^{(2)}$, Juraci Alves Oliveira ${ }^{(4)} \&$ Walter Lee Daniels ${ }^{(5)}$
}

\begin{abstract}
Phytoremediation strategies utilize plants to decontaminate or immobilize soil pollutants. Among soil pollutants, metalloid As is considered a primary concern as a toxic element to organisms. Arsenic concentrations in the soil result from anthropogenic activities such as: the use of pesticides (herbicides and fungicides); some fertilizers; $\mathrm{Au}, \mathrm{Pb}, \mathrm{Cu}$ and $\mathrm{Ni}$ mining; $\mathrm{Fe}$ and steel production; coal combustion; and as a bi-product during natural gas extraction. This study evaluated the potential of pigeon pea (Cajanus cajan), wand riverhemp (Sesbania virgata), and lead tree (Leucaena leucocephala) as phytoremediators of soils polluted by As. Soil samples were placed in plastic pots, incubated with different As doses (0; 50; 100 and $200 \mathrm{mg} \mathrm{dm}^{-3}$ ) and then sown with seeds of the three species. Thirty (pigeon pea) and 90 days after sowing, the plants were evaluated for height, collar diameter and dry matter of young, intermediate and basal leaves, stems and roots. Arsenic concentration was determined in different aged leaves, stems and roots to establish the translocation index (TI) between the plant root system and aerial plant components and the bioconcentration factors (BF). The evaluated species showed distinct characteristics regarding As tolerance, since the lead tree and wand riverhemp were significantly more tolerant than pigeon pea. The high As levels found in wand riverhemp roots suggest the existence of an efficient accumulation and compartmentalization mechanism in order to reduce As translocation to shoot
\end{abstract}

\footnotetext{
(1) Received for publication in Juny 2009 and approved in March 2010.

(2) Associated Professors, Soil Dep. Universidade Federal de Viçosa - UFV. CEP 36571-000 Viçosa (MG). CNPq grant holders. Emails: ledias@ufv.br; jwvmello@ufv.br

(3) Researcher III, Agric. Res. Center of the Semi-Arid Tropics (EMBRAPA-CPATSA), P.Box 23, CEP 56302-970 Petrolina (PE). E-mail: roseli.melo@cpatsa.embrap.br

(4) Associated. Professor. Biology Dep. Soil Dep. Universidade Federal de Viçosa - UFV, CEP 36571-000 Viçosa (MG).

(5) Professor, Dep. of Crop and Soil Environmental Sciences, VITECH, Blacksburg, Virginia 24061 0404. E-mail: wdaniels@vt.edu
} 


\begin{abstract}
tissues. Pigeon pea is a sensitive species and could serve as a potential bioindicator plant, whereas the other two species have potential for phytoremediation programs in As polluted areas. However, further studies are needed with longer exposure times in actual field conditions to reach definite conclusions on relative phytoremediation potentials.
\end{abstract}

Index terms: remediation, decontamination, phytoremediation, phytostabilization.

\author{
RESUMO: CRESCIMENTO DE MUDAS DE FEIJÃO-GUANDU (Cajanus cajan \\ (L.) MILLSP), SESBANIA (Sesbania virgata (CAV.) PERS.) E \\ LEUCENA (Leucaena leucocephala (LAM.) DE WIT) EM SOLO \\ CONTAMINADO POR ARSENNIO
}

\begin{abstract}
A fitorremediação é uma estratégia que utiliza plantas para descontaminar ou imobilizar poluentes do solo. Entre os poluentes do solo, o As é considerado o principal elemento tóxico aos organismos vivos. A presença de As no solo pode ser decorrente de atividades antrópicas, como: uso de pesticidas (herbicidas e fungicidas); alguns fertilizantes; extração de $\mathrm{Au}, \mathrm{Pb}, \mathrm{Cu}$ e $\mathrm{Ni}$; produção de Fe e aço; combustão de carvão; e coprodução durante a extração de gás natural. Este trabalho avaliou o potencial de feijão-guandu (Cajanus cajan), sesbania (Sesbania virgata) e leucena (Leucaena leucocephala) como fitorremediadoras de solos contaminados por As. Amostras de solo foram colocadas em potes de plástico, incubadas com diferentes doses de As (0, 50, 100 e $\left.200 \mathrm{mg} \mathrm{dm}^{-3}\right)$ e semeados com sementes das três espécies. Aos 30 (feijãoguandu) e aos 90 dias após a semeadura, as plantas foram avaliadas quanto a altura, diâmetro de colo e matéria seca de folhas jovens, intermediárias e basais, ramos e raízes. A concentração de As foi determinada nas diferentes folhas, ramos e raizes, a fim de estabelecer o indice de translocação (TI) entre o sistema radicular e a parte aere das plantas e o fator de bioconcentração (BF). As espécies avaliadas apresentaram comportamento distinto em relação à tolerância ao As, uma vez que a sesbania e a leucena foram significativamente mais tolerantes que o feijão guandu. A elevada concentração de As encontrada nas raizes de sesbania sugere a existência de um eficiente mecanismo de acumulação e compartimentalização, no sentido de reduzir a translocação para os tecidos da parte aérea. O feijão-guandu é uma espécie sensivel ao As, podendo ser utilizado como planta indicadora, enquanto as outras duas espécies apresentam potencial para serem utilizadas em programas de fitorremediação de áreas contaminadas por As. Entretanto, estudos futuros em condições de campo e de longa duração são necessários para a obtenção de conclusões definitivas em relação ao potencial de fitorremediação dessas espécies.
\end{abstract}

Termos de indexação: remediação, descontaminação, fitorremediação, fitoestabilização.

\section{INTRODUCTION}

Metalloid As is highly toxic. Concentrations below $10 \mathrm{mg} \mathrm{kg}^{-1}$ are common in non-polluted soils (Adriano, 2001), whereas in polluted areas, the As concentration can achieve values three thousand times higher (Vaughan, 1993). High As concentrations in the soil result from anthropogenic activities such as: the use of pesticides and fertilizers; mining activities; $\mathrm{Fe}$ and steel production; and coal combustion and extraction (Smith et al., 1998). Phytoremediation has been considered as an emerging low-cost technique to reclaim areas polluted by toxic elements. Few species, however, have been reported as capable of accumulating As.

Despite the existence of many sources of soil contamination, there are few studies related to tolerance, absorption and translocation of As in shrub plants. These have been widely studied for other metals in polluted environments. For this reason, the knowledge of patterns of absorption, translocation and accumulation of ions such as As, the tolerance limits and phytotoxicity symptoms of species with potential for phytoremediation has gained importance (Huang \& Cunningham, 1996, Visoottiviseth et al., 2002). The in-situ application of technologies using plants for immobilization and/or stabilization of toxic metals appears economical rather than other ex-situ non-biological remediation techniques (Glass, 1997; Susarla et al., 2002).

The selection strategies of a suitable plant species for managing high metal and metalloid concentrations in the rhizosphere can be divided into two groups: plants that use exclusion mechanisms, restricting the 
absorption and/or transport to the aerial parts; and the development of internal immobilization mechanisms, compartmentalization or detoxification via production of compounds that promote stable bonds with metals and metalloids (Marschner, 1995; Küpper et al., 1999).

Among these there are several species used to reclaim mined areas. Those belonging to the family Leguminosae have shown good vegetative growth, even in substrata with very unfavorable physical and chemical conditions (Franco et al., 2000; Dias et al., 2008).

The objective of this work was to determine the potential of pigeon pea, wand riverhemp, and lead tree for potential phytoremediation and/or revegetation of As-polluted areas.

\section{MATERIAL AND METHODS}

Subsurface samples $(20-40 \mathrm{~cm})$ of a Typic Haplustox (Latossolo Vermelho-Amarelo according Brazilian Soil Classification System) (Table 1) were collected from the region of João Pinheiro, State of Minas Gerais, Brazil. The soil samples were ground, sieved (4 mm) and incubated for 15 days with different As (V) $\left(\mathrm{Na}_{2} \mathrm{HAsO}_{4}\right)$ doses: 0; 50; 100; and $200 \mathrm{mg} \mathrm{dm}^{-3}$. According to previous tests carried out with the same soil samples, the addition of these doses resulted in 0 ; $12.7 ; 27.4$; and $58.9 \mathrm{mg} \mathrm{dm}^{-3}$ of available As respectively, by Mehlich-3 extractor.

The use of $\mathrm{Na}$ arsenate as the As source originally was a concern due to potential $\mathrm{Na}$ availability in the system, which was $15.4 ; 30.8 ; 61.6 \mathrm{mg} \mathrm{dm}^{-3}$ for 50 ; 100 and $200 \mathrm{mg} \mathrm{dm}^{-3}$ of $\mathrm{As}\left(\mathrm{Na}_{2} \mathrm{HAsO}_{4}\right)$ respectively. A preliminary test carried out with pigeon pea and the equivalent doses of $\mathrm{Na}$ did not show toxic effects in the plants. The soil solution electrical conductivity (1:1 soil-water ratio) ranged from 0.1 to $0.3 \mathrm{dS} \mathrm{m}^{-1}$.

After incubation, $1.39 \mathrm{dm}^{3}$ of soil samples were placed in plastic pots in which seeds of pigeon pea (Cajanus cajan L. Millsp), wand riverhemp. (Sesbania virgata Cav) and lead tree (Leucaena leucocephala L.) were sown. Thinning was carried out eight days after emergence, leaving three plants per pot.

Macronutrient fertilization was applied at nine days after emergence, with $60 \mathrm{mg} \mathrm{dm}^{-3}$ of $\mathrm{N}$, $100 \mathrm{mg} \mathrm{dm}^{-3}$ of $\mathrm{P}$ and $\mathrm{K}$ and $50 \mathrm{mg} \mathrm{dm}^{-3}$ of $\mathrm{Mg}$, in the form of solutions of ammonium phosphate, ammonium nitrate, calcium phosphate, potassium phosphate and magnesium sulphate. To guarantee adequate $\mathrm{N}$ supply to the plants we chose not to inoculate the seeds with $\mathrm{N}_{2}$-fixing bacteria. For wand riverhemp and lead tree the $\mathrm{N}$ fertilization was divided in two applications, at nine and 35 days after emergence and for pigeon pea the fertilization was done once at nine days after the emergence.

Micronutrient fertilization was applied in the form of solutions equally divided in four applications (15, 30,45 and 60 days after emergence), with total doses of $0.81 ; 3.66,4 ; 1.33 ; 0.15$ and $1.56 \mathrm{mg} \mathrm{dm}^{-3}$ of $\mathrm{B}, \mathrm{Mn}$, $\mathrm{Zn}, \mathrm{Cu}, \mathrm{Mo}$ and Fe respectively.

The experiment was conducted in a greenhouse, in a randomised block design, with three replications. During the experimental period the temperature in the greenhouse ranged from 20.4 to $31.3^{\circ} \mathrm{C}$, and the relative humidity from 50 to $69 \%$.

At 30 days after sowing, the pigeon pea plants were evaluated for height and collar diameter (just above the soil surface) and then cut at ground level. Afterwards, the plants were separated into young $(\mathrm{YL})$, mature (ML) and old (OL) leaves, stem (C) and roots $(\mathrm{R})$. For the other two species this procedure was done at 90 days after sowing. Roots were washed with tap water to remove soil, clipped and then placed in $0.1 \mathrm{~mol} \mathrm{~L}^{-1} \mathrm{HCl}$ solution for approximately $1 \mathrm{~min}$, which was followed by several rinses with deionized water. Also, soil samples were collected from each pot in order to determine the concentration of available As using the Mehlich-3 extraction technique (Ribeiro Jr. et al., 2004).

To separate the different types of leaves, we considered the tender and not completely expanded leaves along with their shoots, as young, whereas the

Table 1. Chemical and physical characteristics of the Typic Haplustox sample used in the experiment

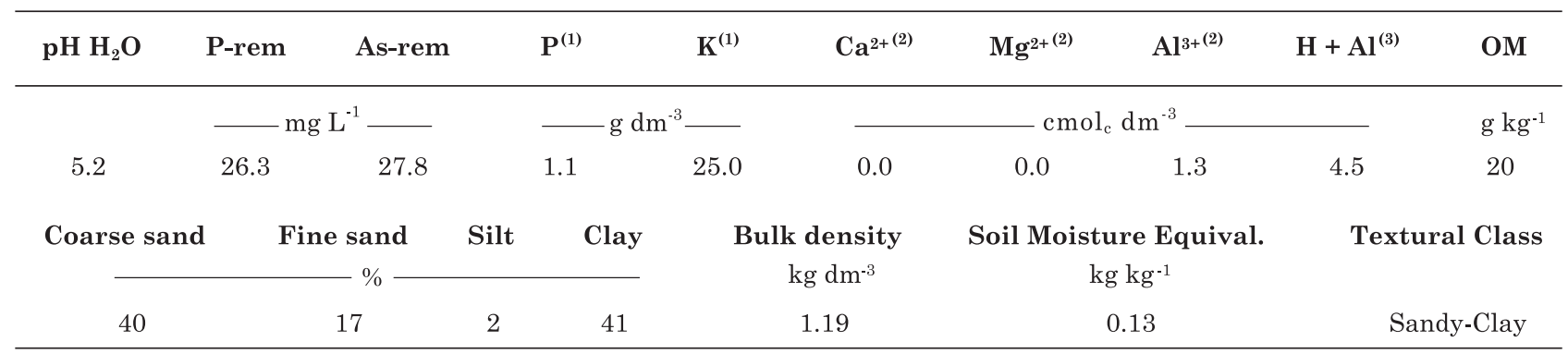

(1) Extractor Mehlich-1 (Mehlich, 1984). ${ }^{(2)}$ Extractor $\mathrm{KCl} \mathrm{mol} \mathrm{L}{ }^{-1} .{ }^{(3)} \mathrm{H}+\mathrm{Al}$ a pH 7,0 with calcium acetate 1 mol L ${ }^{-1}$; P-rem: soil remaining $\mathrm{P}$ and As-Rem: soil remaining arsenic, according to Alvarez V. et al. (2001) and Ribeiro Jr. et al. (2004), respectively. 
basal leaves were those mature and at senescence stage (yellowish), and all others as mature. The plant parts were dried in a forced-air oven at $60-70{ }^{\circ} \mathrm{C}$ to a constant weight to determine dry matter mass.

Arsenic concentration in the different plant parts was determined using $1 \mathrm{~g}$ samples of dried finelyground material that was digested in an $\mathrm{HNO}_{3}: \mathrm{HClO}_{4}$ concentrated solution $(3: 1 \mathrm{v} / \mathrm{v})$. The samples were digested in a block digestor under controlled temperatures: initially at $50{ }^{\circ} \mathrm{C}$ for approximately $30 \mathrm{~min}$; then $100{ }^{\circ} \mathrm{C}$ for an additional $30 \mathrm{~min}$; and finally between 160 and $180{ }^{\circ} \mathrm{C}$ to complete the digestion.

Arsenic concentration in the plant extracts and available As in the soil (Mehlich-3) were determined by inductive coupled plasma atomic emission spectrometry (ICP/OES) at $193.697 \mathrm{~nm}$. A standard reference material (GBW07603 bush branches and leaves, provided by the Geophysical and Geochemical Exploration-Langtang-China Institute) was analyzed to validate the method used in this research.

The amount of accumulated As was used to calculate the As translocation index (TI), according to Abichequer \& Bohnen (1998), with the following equation:

$$
T I(\%)=\frac{\text { Amount of As accumulated in the aerial parts }(\text { leaves }+ \text { stem })}{\text { Amount of As accumulated in the plant }} \times 100
$$

Only the As concentration in plant tissue is not a good indicator of the potential of element bioconcentration for the plant (Tu et al., 2002). For a better evaluation of this potential the authors used the bioconcentration factor $(\mathrm{BF})$ that is the relation between As concentration in the plant tissue and soil As concentration. Values above 1.0 indicate that the species is As bioconcentrating. For the calculation of this factor the authors used as an As soil concentration the value applied to the soil. Considering that the As in the soil can be adsorbed, mainly, from oxides and hydroxides of $\mathrm{Fe}$ and of $\mathrm{Al}$, a significant portion of the added element can be in a non available form for the plant. Therefore, in this work the bioconcentration factor was calculated using As available in the soil by the Mehlich-3 extraction, which showed to be a good extraction method to predict the available forms of As (Ribeiro Jr., 2002).

Equations to represent the behavior of plants as a function of different As doses were obtained by regression analysis to the following variables: shoot (SDM), roots (RDM) and total (TDM) dry matter; As concentration in young leaves (YL), mature leaves (ML), old leaves (OL), stem (S) and roots (R); soil available As at the end of the experiment (SAA); shoot As content (SAC), roots As content (RAC) and total plant As content (TPAC). The coefficients of the obtained equations were tested by the "F" test at 1 and $5 \%$.
The As doses which caused a reduction of $50 \%$ of shoot dry matter were obtained by regression analysis, considering the dry matter of the shoot as function of applied As doses. The regression equations for soil available arsenic as function As applied dose, allowed to estimate the level of soil available As (SAs $50 \%$ ) that provided a reduction of $50 \%$ of shoot dry matter.

\section{RESULTS AND DISCUSSION}

\section{Phytotoxicity symptoms, dry matter production, plant diameter and plant height}

Pigeon pea plants from the highest As doses (200 $\mathrm{mg} \mathrm{dm}^{-3}$ of As) showed a marked decrease in growth and strong As toxicity symptoms, which resulted in their harvest after 30 days of exposure to As. The symptoms were characterized by intervein chlorosis followed by wilting and tissue necrosis (Adriano, 1986). The same symptoms were also observed with oat (Avena strigosa Schreb) submitted to the same experimental conditions Melo et al. (2009).

Arsenic toxicity can arise from the inhibition of several mitochondrial enzymes and deactivation of oxidative phosphorylation, impairing cellular respiration. A great part of As toxicity results from its capacity to interact with sulphydryl groups of proteins and enzymes, and also the capacity to replace P in several reactions (Goyer, 1996).

The pigeon pea sensibility to As can be confirmed by reductions in dry matter of the roots, shoots (Figure 1) height and collar diameter by 75, 74, 55 and $8 \%$ respectively, at a treatment level of $100 \mathrm{mg} \mathrm{dm}^{-3} \mathrm{As}$, in comparison to the control plants.

Lead tree and wand riverhemp were more tolerant to the presence of As. The lead tree shoots, root and total dry matter (Figure 1) and height were reduced by $36,27,33,29 \%$ respectively, with the highest dose (200 $\mathrm{mg} \mathrm{dm}^{-3}$ ), compared to the control (dose 0). For wand riverhemp, the biomass was reduced to about $47,34,45$ and $23 \%$ respectively, compared to the control plants.

The highest root and total dry matter of lead trees was observed at the $50 \mathrm{mg} \mathrm{dm}^{-3}$ As dose (Figure 1). This stimulatory behavior of this species agrees with findings reported by Ma et al. (2001) where they have shown that some species show some stimulated growth under low concentrations of available As. When exposed to $50 \mathrm{mg} \mathrm{dm}^{-3} \mathrm{As}$, the plants of riverhemp formed nodules in its root system, but we did not examine their capacity for $\mathrm{N}_{2}$-fixation activity.

\section{Distribution of As in different plant compartments}

The increasing As doses significantly affected $(p=$ $0.01)$ its concentration in the different plant parts of 

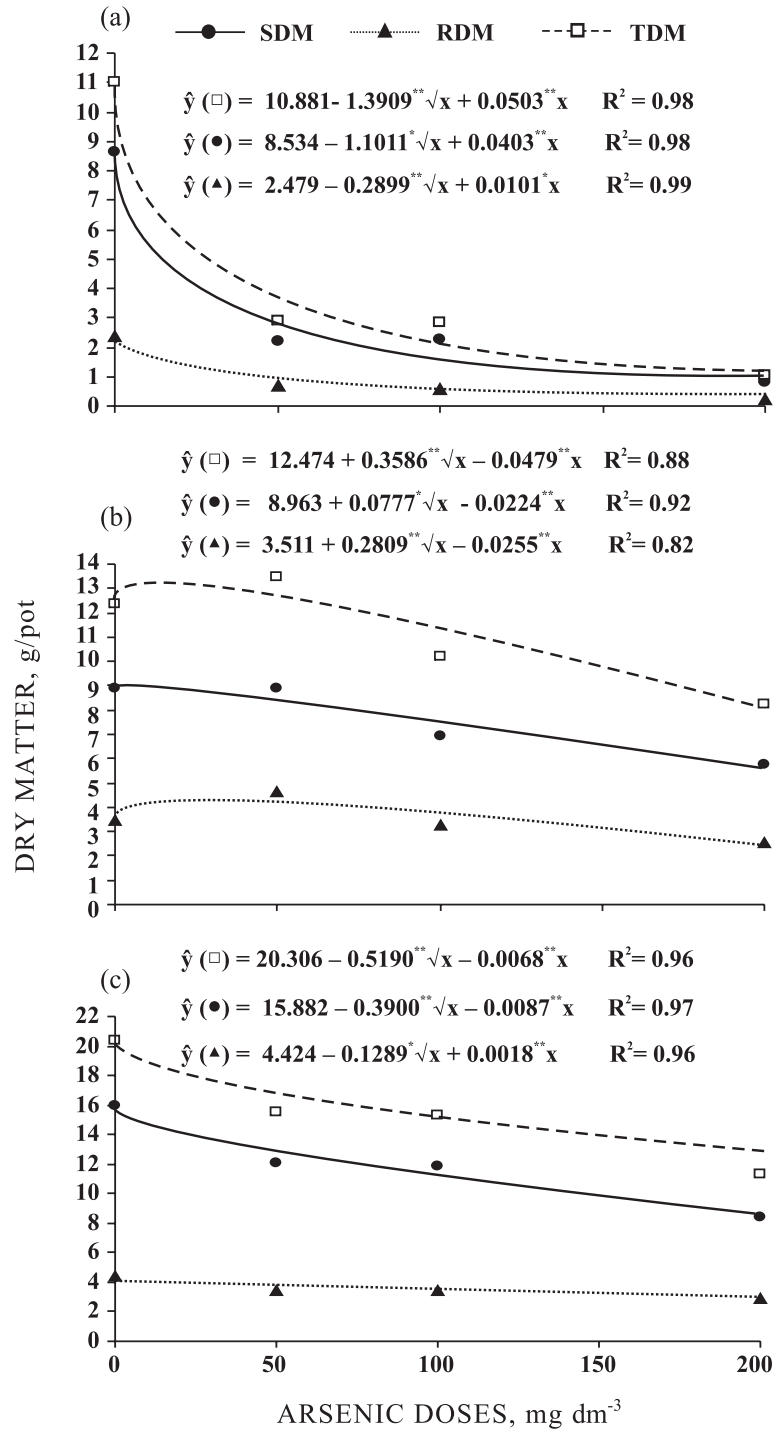

Figure 1. Shoot (SDM), Roots (RDM) and Total (TDM) dry matter of pigeon pea (a), lead tree (b) and wand riverhemp (c) as a function of different arsenic doses. ** and * means that the coefficients of the equations are significant at 1 and $5 \%$, respectively, and consequently the effect of doses is also significant.

all species (Tables 2 and 3). Overall, the As concentration in the plant parts occurred in the acropetal direction (from base to apex). The highest root As concentrations were found in lead trees and wand riverhemp plants (Table 2).

These results agree with those observed of mustard (Pickering et al., 2000); however, they diverge from those found for hyperaccumulative plants such as Pteris vittata (Ma et al., 2001) and Pityrogramma calomelano (Vissottiviseth et al., 2002) which showed larger accumulations in the leaves. However, the capacity for As translocation to aerial plant parts is a function of tolerance mechanisms that vary among species.
The As content in young and mature leaves of pigeon pea showed similar values for the highest dose (200 $\mathrm{mg} \mathrm{dm}^{-3}$ ), but was significantly higher in basal (old) leaves and stems. Pigeon pea roots had an As content (87.1 $\mathrm{mg} \mathrm{kg}^{-1}$ ) lower than those found in roots of lead tree $\left(284.9 \mathrm{mg} \mathrm{kg}^{-1}\right)$ and wand riverhemp (772.2 $\left.\mathrm{mg} \mathrm{kg}^{-1}\right)$.

The As content in shoot compartments of pigeon pea were relatively high compared to normal limits in plants (5 $\mathrm{mg} \mathrm{kg}^{-1}$ ) (Wauchope, 1983). Such distribution associated with the large decrease in biomass suggests the lack of more efficient mechanisms of tolerance to the metalloid, with reduced retention in roots and resulting damages to aerial parts. This also suggests the lack of an effective mechanism of internal control to avoid the metalloid translocation to tissues of aerial parts, reducing biomass production and therefore increasing As concentration in such compartments.

Leaves of lead tree had relatively low As contents, particularly the young leaves (Table 2). The highest As levels were found with $100 \mathrm{mg} \mathrm{dm}^{-3}\left(8.4 \mathrm{mg} \mathrm{kg}^{-1}\right)$ in old leaves (OL). The stem had the highest content with $80 \mathrm{mg} \mathrm{kg}^{-1}$. In the shoot parts, roots and total plant, As contents were fitted to both square root and quadratic models (Table 3).

Arsenic content in leaves of wand riverhemp ranged from $5.0 \mathrm{mg} \mathrm{kg}^{-1}$ for young leaves (YL) to $29.7 \mathrm{mg} \mathrm{kg}^{-1}$ for old leaves (OL), with 100 and $200 \mathrm{mg} \mathrm{dm}^{-3}$ treatments, respectively (Table 2). Arsenic content in stems exhibited a square root response to treatments (Table 3).

Roots of wand riverhemp had relatively high As contents, reaching $772 \mathrm{mg} \mathrm{kg}^{-1}$ with $200 \mathrm{mg} \mathrm{dm}^{-3} \mathrm{As}$. This value can be 13.1 fold higher than the concentration of As available in the soil and 154 fold higher than the limit found in normal plants $\left(5 \mathrm{mg} \mathrm{kg}^{-1}\right)$. Some plants can accumulate high levels of metals, ranging from 100 fold to 1,000 fold higher than the normal level accumulated by most species, which is 0.1-5 mg kg-1 (Wauchope, 1983).

Wand riverhemp had a quadratic response to the As contents in shoots, roots and total plant (Table 3), which was a function of the As applied. Overall, the lead trees and wand riverhemp plants were more tolerant to As in the soil. These species showed high accumulative capacity, mainly in the root system, showing potential for As phytostabilization.

Root system volume is an important characteristic related to a higher capacity for absorption and accumulation of As between accumulative and nonaccumulative plants. The As hyperaccumulative species Chinese brake fern (Pteris vitatta) has a root system volume that is 4 -fold larger and accumulated 29-fold more As than Nephrolepis exaltata L. (As nonaccumulative species) (Gonzaga et al., 2006). This behavior is somewhat expected, as arsenate shows low mobility in the soil, particularly in predominantly oxisols. Therefore, the larger the root system volume, 
Table 2. Arsenic concentration in young leaves (YL), mature leaves (ML), old leaves (OL), stem (S) and roots (R) of pigeon pea, lead tree and wand riverhemp as a function of different arsenic doses

\begin{tabular}{|c|c|c|c|c|c|c|}
\hline Species & Dosis & YL & ML & OL & $\mathbf{S}$ & $\mathbf{R}$ \\
\hline & $\mathrm{mg} \mathrm{dm}^{-3}$ & 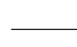 & 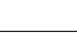 & $\mathrm{mg} \mathrm{kg}$ & & - \\
\hline \multirow[t]{5}{*}{ Pigeon pea } & 0 & -(1) & - & - & - & - \\
\hline & 50 & 7.3 & 7.3 & 12.2 & 26.2 & 14.1 \\
\hline & 100 & 7.2 & 7.2 & 23.8 & 38.8 & 56.4 \\
\hline & 200 & 12.1 & 13.6 & 55.1 & 83.1 & 87.1 \\
\hline & $\mathrm{CV}(\%)^{(2)}$ & 11.0 & 9.9 & 2.9 & 6.0 & 5.9 \\
\hline \multirow[t]{5}{*}{ Lead tree } & 0 & - & - & - & - & - \\
\hline & 50 & - & 2.5 & 5.6 & 0.6 & 92.6 \\
\hline & 100 & 0.5 & 2.8 & 8.4 & 1.3 & 267.5 \\
\hline & 200 & 0.6 & 3.0 & 5.8 & 1.0 & 284.9 \\
\hline & $\mathrm{CV}(\%)$ & 18.2 & 13.1 & 5.6 & 9.6 & 3.4 \\
\hline \multirow[t]{5}{*}{ Wand riverhemp } & 0 & - & - & - & - & - \\
\hline & 50 & 3.4 & 7.2 & 6.8 & 1.6 & 254.8 \\
\hline & 100 & 5.0 & 12.7 & 17.1 & 2.9 & 466.2 \\
\hline & 200 & 4.5 & 17.2 & 29.7 & 3.0 & 772.2 \\
\hline & CV (\%) & 4.0 & 2.5 & 4.6 & 7.4 & 2.6 \\
\hline
\end{tabular}

(1) Concentration below detection limited by used method (ICP/OES). ${ }^{(2)}$ Coefficient of variation across the treatments.

Table 3. Regression equations for arsenic concentration in young leaves (YL), mature leaves (ML), old leaves $(\mathrm{OL})$, stem (S) and roots (R), soil available arsenic at the end of the experiment (SAA), shoot arsenic content (SAC), root arsenic content (RAC) and total plant arsenic content (TPAC) of pigeon pea, lead tree and wand riverhemp as a function of different arsenic doses

\begin{tabular}{|c|c|c|c|}
\hline Species & Compartment & Equation & $\mathbf{R}^{2}$ \\
\hline Pigeon pea & $\begin{array}{l}\mathrm{YL}^{(1)} \\
\mathrm{ML}^{(1)} \\
\mathrm{OL}^{(1)} \\
\mathrm{S}^{(1)} \\
\mathrm{R}^{(1)} \\
\mathrm{SAA}^{(2)} \\
\mathrm{SAC}^{(3)} \\
\operatorname{RAC}^{(3)} \\
\operatorname{TPAC}^{(3)}\end{array}$ & $\begin{array}{l}\hat{y}=0.163+0.8910^{* *} \sqrt{ } x-0.0054^{* *} x \\
\hat{y}=0.194+0.7183^{* *} \sqrt{ } x-0.0140^{* *} x \\
\hat{y}=0.269+0.2079^{* *} x+0.0003^{* *} x^{2} \\
\hat{y}=1.634+0.4049^{* *} x \\
\hat{y}=-3.778+0.5925^{* *} x-0.0007^{* *} x^{2} \\
\hat{y}=-4.189+0.3075^{* *} x \\
\hat{y}=0.001+0.0028^{* *} x-0.00001^{* *} x^{2} \\
\hat{y}=-0.003+0.0005^{* *} x-0.000002^{* *} x^{2} \\
\hat{y}=-0.002+0.0033^{* *} x-0.000013^{* *} x^{2}\end{array}$ & $\begin{array}{l}0.96 \\
0.95 \\
0.99 \\
0.99 \\
0.96 \\
0.98 \\
0.99 \\
0.85 \\
0.99\end{array}$ \\
\hline Lead tree & $\begin{array}{l}\text { YL } \\
\text { ML } \\
\text { OL } \\
\text { S } \\
\text { R } \\
\text { SAA } \\
\text { SAC } \\
\text { RAC } \\
\text { TPAC } \\
\text { YL }\end{array}$ & $\begin{array}{l}\hat{y}=-0.017+0.0032^{* *} \mathrm{x} \\
\hat{y}=0.003+0.4719^{* *} \sqrt{ } \mathrm{x}-0.0189^{* *} \mathrm{x} \\
\hat{y}=0.123+0.1267 \mathrm{x}^{* *}-0.0005^{* *} \mathrm{x}^{2} \\
\hat{y}=-0.037+0.0192^{* *} \mathrm{x}-0.00007^{* *} \mathrm{x}^{2} \\
\hat{y}=-15.696+3.4891^{* *} \mathrm{x}-0.0097^{* *} \mathrm{x}^{2} \\
\hat{y}=-0.082+0.0745^{* *} \mathrm{x}+0.00046^{* *} \mathrm{x}^{2} \\
\hat{y}=-0.0003+0.0149^{* *} \sqrt{ } \mathrm{x}-0.0007^{* *} \mathrm{x} \\
\hat{y}=-0.037+0.0121^{* *} \mathrm{x}-0.00004^{* *} \mathrm{x}^{2} \\
\hat{y}=-0.034+0.0135^{* *} \mathrm{x}-0.000046^{* *} \mathrm{x}^{2} \\
\hat{y}=-0.018+0.7565^{* *} \sqrt{ } \mathrm{x}-0.0286^{* *} \mathrm{x}\end{array}$ & $\begin{array}{l}0.80 \\
0.99 \\
0.99 \\
0.98 \\
0.95 \\
0.99 \\
0.99 \\
0.96 \\
0.97 \\
0.99\end{array}$ \\
\hline Wand riverhemp & $\begin{array}{l}\text { ML } \\
\text { OL } \\
\text { S } \\
\text { R } \\
\text { SAA } \\
\text { SAC } \\
\text { RAC } \\
\text { TPAC }\end{array}$ & $\begin{array}{l}\hat{y}=-0.043+0.1671^{* *} x-0.0004^{* *} x^{2} \\
\hat{y}=-0.519+0.1804^{* *} x-0.00014^{*} x^{2} \\
\hat{y}=-0.042+0.0430^{* *} x-0.00014^{* *} x^{2} \\
\hat{y}=-1.965+213433^{* *} \sqrt{ } x+2.3851^{* *} x \\
\hat{y}=0.051+0.0743^{* *} x+0.0006^{* *} x^{2} \\
\hat{y}=-0.010+0.00638^{* *} x-0.00002^{* *} x^{2} \\
\hat{y}=-0.016+0.0209^{* *} x-0.00005^{* *} x^{2} \\
\hat{y}=-0.021+0.0273^{* *} x-0.00007^{* *} x^{2}\end{array}$ & $\begin{array}{l}0.99 \\
0.99 \\
0.99 \\
0.99 \\
0.99 \\
0.98 \\
0.99 \\
0.99\end{array}$ \\
\hline
\end{tabular}

(1) Arsenic concentration $\left(\mathrm{mg} \mathrm{kg}^{-1}\right) .{ }^{(2)}$ Available arsenic by Mehlich-3. ${ }^{(3)}$ Arsenic content (mg/pot). 
the larger the amount of As that may be assimilated by the plant (Geng et al., 2006).

\section{Translocation index}

The application of different As doses to the soil resulted in significant differences $(p=0.01)$ in As translocation indexes (TI) from roots to shoot parts. The TIs found for pigeon pea were considerably high, and the highest index $(91.9 \%)$ was found with $50 \mathrm{mg} \mathrm{dm}^{-3}$, followed by 83.8 and $87.0 \%$ for the doses 100 and $200 \mathrm{mg} \mathrm{dm}^{-3}$ respectively (Figure 2). Contrary to this behavior, lead trees and wand riverhemp plants had relatively low TI values, and the highest indexes were found for 50 and $100 \mathrm{mg} \mathrm{dm}^{-3}$ doses with percent translocations of 16.2 and $9.6 \%$ for lead tree, and 20.9 and $21.6 \%$ for wand riverhemp, respectively (Figure 2)

A larger accumulation of As in the root system compared with the shoot parts may indicate a low capacity for controlling the As absorption and/or a higher efficiency in restraining the translocation, avoiding As reaching the metabolically more active tissues of the shoots parts. This mechanism may be related to phytochelatin synthesis (Cobbett \& Goldsbrough, 2002). These peptides are synthesized from glutathione and play a fundamental role in As detoxification by the formation of stable bonds with the As (Sneller et al., 1999; Meharg \& HartleyWhitaker, 2002; Inohue, 2005). In this context, the knowledge of As distribution in plants allows a better evaluation of these potential species for programs of phytoremediation and/or revegetation, as well as their risks to the environment, mainly concerning species that may enter the trophic chain.

The soil available As (SAs50 \%) that provided a reduction of $50 \%$ of shoot dry matter for pigeon pea

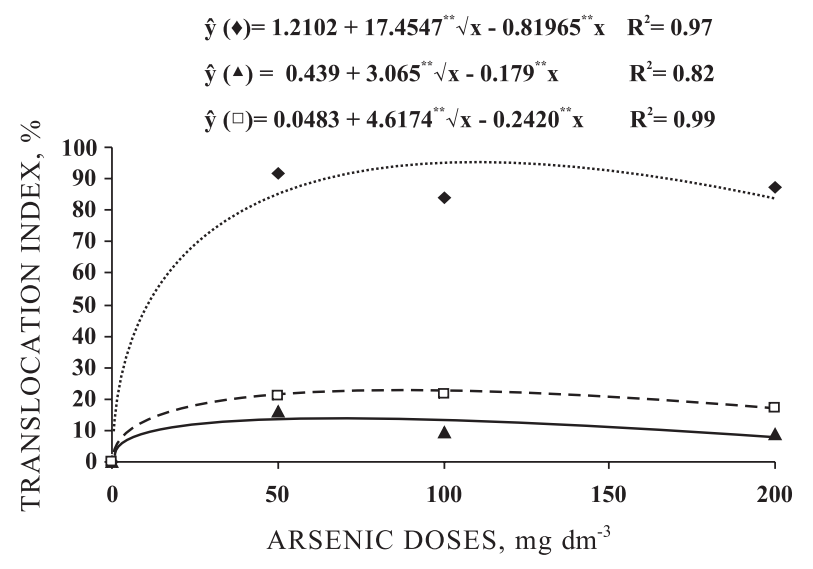

Figure 2. Arsenic translocation index in plants of pigeon pea $(\diamond)$, lead tree $(\Delta)$ and wand riverhemp ( $\square$ ) as a function of different arsenic doses. **and * means that the coefficients of the equations are significant at 1 and $5 \%$, respectively, and consequently the effect of the doses is also significant.

was very low to shoot (except to $50 \mathrm{mg} \mathrm{dm}^{-3}$ ) and roots dry matter (Table 4), confirming the high Assensibility of this species. As-soluble concentrations ranging from 1 to $10 \mathrm{mg} \mathrm{kg}^{-1}$ are toxic for beans, alfalfa and rice (Bishop \& Chisholm, 1962). Evaluating the As-tolerance by sorghum, Ribeiro Jr (2002) observed that one value of $26.9 \mathrm{mg} \mathrm{dm}^{-3}$ of available As (Mehlich-3) promoted the death of all plants in greenhouse conditions.

Wand riverhemp and lead tree showed high SAs50 \% to roots dry matter (Table 4). The obtained value to wand riverhemp is about 92 times superior

Table 4. Soil arsenic available that provided a reduction of $50 \%$ (SAs50 \%) roots and shoot dry matter and arsenic bioconcentration factors (BF) to pigeon pea, lead tree and wand riverhemp, as influenced by arsenic doses applied to soil

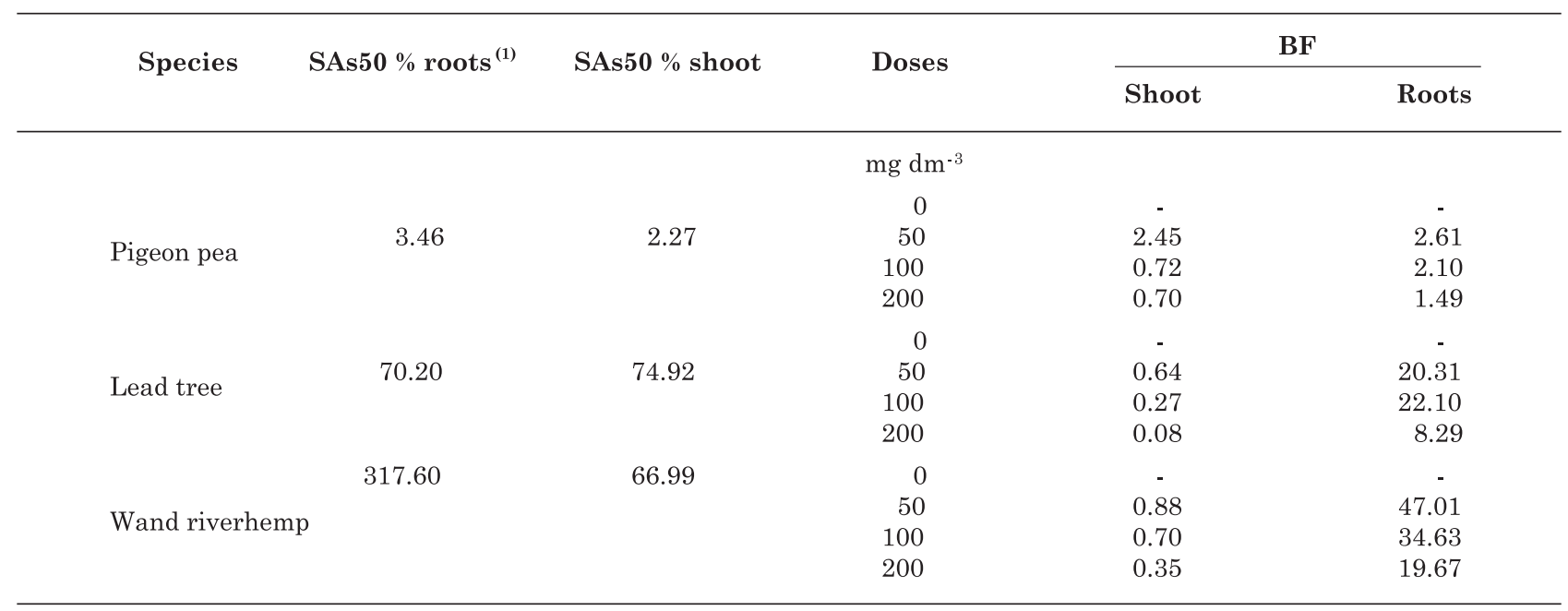


to that required by the pigeon pea, reinforcing its efficient mechanism to restrain the translocation, to avoid that As reaches the metabolically more active tissues of the shoots parts. This difference of behavior among the species can have a genetic or physiologic base, as the possible existence of phytochelatin in the roots, capable to complex and to transport the As for the vacuole avoiding, as such, the toxicity of the plants (Ma et al., 2001; Inohue, 2005).

\section{Bioconcentration factor}

Just for the pigeon pea in the dose of $50 \mathrm{mg} \mathrm{dm}^{-3}$, a value of superior BF to 1.0 for the aerial part of the plants was obtained. For the other species, superior values to 1.0 were just obtained for the root systems (Table 4). As such, considering that the dose of $50 \mathrm{mg} \mathrm{dm}^{-3}$ As resulted in the available content on the order of $5.0 \mathrm{mg} \mathrm{dm}^{-3}$, the pigeon pea would have a bioacumulator potential of As in soils with contamination levels close to this value. On the other hand, the potential of As accumulation for the wand riverhemp and lead tree root systems showed quite high BF must be considered. This capacity to accumulate As in the root system has a direct relationship with compartimentalization mechanisms that avoid the metalloid being transported to the aerial part and it can commit the photosynthetic activity of the plants. This behavior indicates a good potential for these species to be used for As-phytostabilization.

\section{CONCLUSIONS}

1. The species presented differentiated responses as a function of As doses applied to the soil. Lead tree and wand riverhemp showed greater tolerance, while pigeon pea was more sensitive to As.

2. The As concentration in wand riverhemp roots was considerably higher than lead tree and pigeon pea, suggesting an efficient mechanism of compartmentalization in order to reduce the metalloid translocation to the young tissues of the aerial parts.

3. The low As tolerance of pigeon pea characterizes this species as a potential bioindicator, whereas the other two species show potential for phytostabilization programs.

\section{ACKNOWLEDGMENTS}

To National Council for Scientific and Technological Development (CNPq-CT_Mineral) and Rio Paracatu Mining Company (Kinross Gold Corporation) for the financial support.

\section{LITERATURE CITED}

ABICHEQUER, A.D. \& BOHNEN, H. Eficiência de absorção, translocação e utilização de fósforo por variedades de trigo. R. Bras. Ci. Solo, 22:21-26, 1998.

ADRIANO, D.C. Trace elements in the terrestrial environment. New York, Springer Verlag, 1986. 533p.

ADRIANO, D.C. Trace elements in the terrestrial environment: Biogeochemistry, bioavailability, and risks of metals. New York, Springer Verlag, 2001.867p.

ALVAREZ V., V.H., DIAS, L.E.; RIBEIRO Jr., E.S., SOUZA, R.B. \& FONSECA, C.A. Métodos de análises de enxofre em solos e plantas. Viçosa, MG, Universidade Federal de Viçosa, 2001. 113p.

BISHOP, R.F., \& CHISHOLM, D. Arsenic accumulation in Annapolis Valley orchard soil. Can. J. Soil Sci. 42:77- 80. 1962.

COBBETT, C. \& GOLDSBROUGH, P. Phytochelatins and metallothioneins: Roles in heavy metal detoxification and homeostasis. Ann. Rev. Plant Biol., 53:159-182, 2002.

DIAS, L.E.; FRANCO, A.A.; CAMPELLO, E.F.C.; FARIA, S.M.; CASTILHO, A.; HENRIQUES, J.C. \& DANIELS, W.L. A two-phase process for revegetation of acidic bauxite tailings in the Amazon Region, Brazil. In: NATIONAL MEETING OF THE AMERICA SOCIETY OF MINING AND RECLAMATION, Richmond, 2008. Proceedings. Richmond, New Opportunities to Apply Our Science, ASMR, 2008.CD-ROM.

FRANCO, A.A.; CAMPELLO, E.F.; FARIA, S.M. \& DIAS, L.E. The importance of biological nitrogen fixation on land rehabilitation. In: PEDROSA, F.O.; HUNGRIA, M. \& YATES, G., eds. Nitrogen fixation: From molecules to crop productivity. Dordrecht, Kluwer Academic Pubishers, 2000. p.569-570.

GLASS, D.J. Evaluating phytoremediation potential share of the hazardous site remediation market. In: INTERNATIONAL PHYTOREMEDIATION CONFERENCE, 2., Westborough, 1997. Proceedings. Westborough, IBC Library Service, 1997. p.7-39.

GENG, C.; ZHU, Y.; TONG, Y.; SMITH, S.E. \& SMITH, F.A. Arsenate (As) uptake by and distribution in two cultivars of winter wheat (Triticum aestivum L.). Chemosphere, 62:608-615, 2006.

GONZAGA, M.I.S.; SANTOS, J.A.G. \& MA, L.Q. Arsenic in the rhizosphere of Pteris vittata L. and Nephrolepis exaltata L. Environ. Poll., 143:254-260, 2006.

GOYER R.A. Toxic effects of metals. In: KLAASSEN C.D., ed. Toxicology - The basic science of poisons. New York, Mcgraw Hill, 1996. p.691-736.

HUANG, J.W. \& CUNNINGHAM, S.D. Lead phytoextraction: Species variation in lead uptake and translocation. New Phytol., 134:75-84, 1996. 
INOHUE, M. Phytochelatins. Braz. J. Plant Physiol., 17:65-78, 2005.

KÜPPER, H.; ZHAO, F.J. \& MCGRATH, S.P. Cellular compartmentation of zinc in leaves of the hyperaccumulator Thlaspi caerulescens. Plant Physiol., 119:305-311, 1999 .

MA, L.Q.; KOMAR, K.M.; TU, C.; ZHANG, W.; CAI, Y. \& KENNELLEY, E.D. A fern that hyperaccumulates arsenic. Nature, 409:579, 2001.

MARSCHNER, H. Mineral nutrition of higher plants. 2.ed. San Diego, Academic Press, 1995. 889p.

MEHARG, A.A. \& HARTLEY-WHITAKER, J. Arsenic uptake and metabolism in arsenic resistant and non-resistant plant species. Tansley Review. New Phytol., 154:29-43, 2002.

MEHLICH, A. Mehlich-3 soil test extractant: A modification of Mehlich-2 estractants. Comm. Soil Sci. Plant Anal., 15:1409-1416, 1984.

MELO, R.F.; DIAS, L.E.; MELLO, J.W.V \& OLIVEIRA, J.A. Potencial de quatro espécies herbáceas forrageiras para fitorremediação de solo contaminado por arsênio. R. Bras. Ci. Solo, 33:455-465, 2009.

PICKERING, I.J.; PRINCE, R.C.; GEORGE, M.J.; SMITH, R.D.; GEORGE, G.N. \& SALT, D.E. Reduction and coordination of arsenic in Indian mustard. Plant Physiol., 122:1171. $1177,2000$.

RIBEIRO JR, E.S. Adsorção e dessorção de arsênio em solos e substratos de mineração de ouro e práticas de mitigação de drenagem ácida em colunas de lixiviação. Viçosa, MG, Universidade Federal de Viçosa, 2002. 117p. (Tese de Doutorado)
RIBEIRO, JR, E.S.; DIAS, L.E.; ALVAREZ V., H.V. \& LYNCH, L.S. Arsenate in different soils and gold mining substrates of Minas Gerais State, Brazil. J. Soils Sediments, 4:163169,2004

SMITH, E.; NAIDU, R. \& ALSTON, A.M. Arsenic in the soil environment: A review. Adv. Agron., 64:149-195, 1998.

SNELLER, F.E.C.; van HEERWAARDEN, L.M.; KRAAIJEVELD-SMIT, F.J.L.; TEN BOOKUM, W.M.; KOEVOETS, P.L.M.; SCHAT, H. \& VERKLEIJ, J.A.C. Toxicity of arsenate in Silene vulgaris, accumulation and degradation of arsenate-induced phytochelatins. New Phytol., 144:223-232, 1999.

SUSARLA, S.; MEDINA, V.F. \& MCCUTCHEON, S.C. Phytoremediation: An ecological solution to organic chemical contamination. Ecol. Eng., 18:647-658, 2002.

TU, C.; MA, L.Q. \& BONDADA, B. Arsenic accumulation in the hyperaccumulator Chinese brake and its utilization potential for phytoremediation. J. Environ. Qual., 31:1671-1675, 2002.

VAUGHAN, G.T. The environmental chemistry and fate of arsenical pesticides in cattle tick dip sites and banana land plantations. Melbourne, CSIRO Division of Coal Industry, Center for Advanced Analytical Chemistry, NSW, 1993. 123p.

VISOOTTIVISETH, P.; FRANCESCONIB, K. \& SRIDOKCHANA, W. The potential of Thai indigenous plant species for the phytoremediation of arsenic contaminated land. Environ. Poll., 118:453-461, 2002.

WAUCHOPE, R.D. Uptake, translocation and phytotoxicity of arsenic in plants. In: LEDERER, W.H. \& FENSTERHEIM, R.J., eds. Arsenic: Industrial, biomedical, environmental perspectives. New York, Van Nostrand Reinhold, 1983. p.348-375. 